\title{
Child with hypopyon
}

\author{
Amar Pujari, Shreyas Temkar, Rashmi Singh, Jayanand Urkude
}

Department of Ophthalmology, Dr Rajendra Prasad Centre for Ophthalmic Sciences, All India Institute of Medical Sciences, New Delhi, India

\section{Correspondence to}

Dr Amar Pujari, dramarpujari@gmail.com

Accepted 10 October 2017

\section{CASE DESCRIPTION}

A 9-month-old baby boy presented to our ocular emergency with a complaint of subconjunctival haemorrhage and a small whitish collection along the lower part of the left cornea. Careful history revealed that while mother was stitching a cloth, the child accidentally fell on the needle which she was using; the duration of injury was 6 hours. Examination revealed a lower and temporal subconjunctival haemorrhage and a grossly clear cornea; anterior chamber examination under the slit lamp showed a faintly visible self-sealed lamellar corneal laceration just above the hypopyon. Anterior chamber reaction showed $4+$ cells along with an inferior hypopyon of $0.5 \mathrm{~mm}$ (figure 1A). The pupil was reactive and lens was clear, the fundal glow was mildly obscured and the baby was able to fix at the light source. B-scan ultrasound over the closed eyelids for posterior segment revealed few mild-tomoderate amplitude dot-like spikes in the anterior vitreous cavity without any retinal detachment or retained intraocular foreign body (figure 1B). A provisional diagnosis of post-traumatic self-sealed corneal perforation with acute-onset endophthalmitis was made. Under general anaesthesia, with aseptic precautions, left eye was marked at $2.5 \mathrm{~mm}$ from the limbus, followed by intravitreal injection consisting of vancomycin $(1 \mathrm{mg} / 0.1 \mathrm{~mL})$ and ceftazidime $(2.5 \mathrm{mg} / 0.1 \mathrm{~mL})$, half of this adult dose was administered. Postoperatively, topical moxifloxacin $0.5 \%$ four times a day, prednisolone acetate $1 \%$ six times a day and cycloplegics four times a day were continued for 2 weeks. Systemically, oral
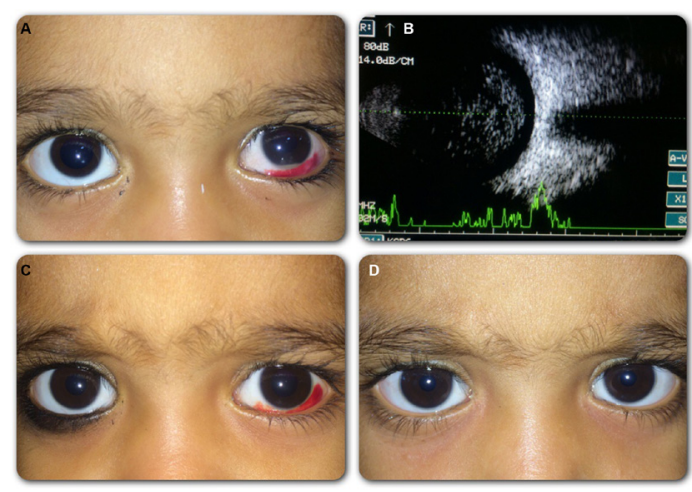

Figure 1 (A) Six hours following injury to the left eye, there was inferior hypopyon of $0.5 \mathrm{~mm}$ along with subconjunctival haemorrhage. (B) Scan ultrasonography showed mild-to-moderate amplitude dot-like echoes suggestive of vitreous exudates. (C) After 48 hours following intravitreal injection, there was a complete resolution of hypopyon. (D) At the end of 3 months, anterior segment was quiet with resolved subconjunctival haemorrhage. amoxicillin/clavulanate $250 \mathrm{mg} / 62.5 \mathrm{mg}$ was advised for 1 week. After 48 hours, there was complete resolution of the hypopyon and the anterior chamber cells reduced to occasional cells (figure 1C). At the end of 3 months, the patient did not encounter any complications (figure 1D).

\section{DISCUSSION}

In general, paediatric cases presenting with hypopyon carries a large number of differential diagnoses such as leukaemia, anterior uveitis, diffuse anterior retinoblastoma, medulloepithelioma, granulomatous disease and others. Under such circumstances, a detailed clinical history, as well as anterior and posterior segment evaluation followed by relevant systemic investigations in doubtful cases is mandatory. The current case under discussion had history of trauma, but still, a suspicion is necessary to rule out all possible highrisk diseases. A diffuse anterior retinoblastoma is known to present as anterior segment infiltrates in absence of retinal foci, the preferred treatment was enucleation because of poor anterior segment reach of chemotherapy but recently globe salvage using brachytherapy has been shown to be effective. Similarly, leukaemia can present as pseudo hypopyon where the symptoms of anaemia may be more pronounced. Anterior uveitis associated with or without granulomatous disease may have other systemic signs of bone-related complaints, recurrent oral ulcers and skin problems. In paediatric age group, penetrating injury (open globe injury) followed by surgery are the most common risk factors for the development of endophthalmitis. ${ }^{12}$ It is an ocular emergency in any group, the evaluation and management should be tailored to each patient. The commonly isolated organisms are Streptococcus and Staphylococcus in post-traumatic and postsurgery endophthalmitis. In uncooperative children, evaluation under anaesthesia may be necessary followed by intravitreal antibiotic administration; the role vitreous tap has mixed opinion. Importantly, because of the poor visual outcome, complications like retinal detachment

\section{Learning points}

- Paediatric cases with hypopyon carry an important group of differential diagnosis; such cases need tailored management plans.

- Endophthalmitis in any age group is an ocular emergency which carries poor prognosis if not addressed at the earliest. 
and others, these cases need optimal treatment protocol for a better outcome. ${ }^{12}$

Contributors All authors have evaluated the case in detail in our ocular emergency followed by optimal management. They were all responsible in analysing the educational value as they worked together in writing the report.

Competing interests None declared.

Patient consent Obtained.

Provenance and peer review Not commissioned; externally peer reviewed. (c) BMJ Publishing Group Ltd (unless otherwise stated in the text of the article) 2017. All rights reserved. No commercial use is permitted unless otherwise expressly granted.

\section{REFERENCES}

1 Thordsen JE, Harris L, Hubbard GB, et al. Pediatric endophthalmitis. A 10-year consecutive series. Retina 2008;28:S3-7.

2 Khan S, Athwal L, Zarbin M, et al. Pediatric infectious endophthalmitis: a review. J Pediatr Ophthalmol Strabismus 2014;51:140-53.

Copyright 2017 BMJ Publishing Group. All rights reserved. For permission to reuse any of this content visit

http://group.bmj.com/group/rights-licensing/permissions.

BMJ Case Report Fellows may re-use this article for personal use and teaching without any further permission.

Become a Fellow of BMJ Case Reports today and you can:

Submit as many cases as you like

- Enjoy fast sympathetic peer review and rapid publication of accepted articles

- Access all the published articles

Re-use any of the published material for personal use and teaching without further permission

For information on Institutional Fellowships contact consortiasales@bmjgroup.com

Visit casereports.bmj.com for more articles like this and to become a Fellow 